\section{Mouse-ear of Pecan: II. Influence of Nutrient Applications}

\author{
Bruce W. Wood ${ }^{1}$, Charles C. Reilly, and Andrew P. Nyczepir \\ U.S. Department of Agriculture, Agricultural Research Service, Southeastern \\ Fruit and Tree Nut Research Laboratory, Byron, GA 31008-0087
}

Additional index words. biennial bearing, flowering, profit, yields, production, stress, growth, nematodes, fungi, culture, phytohormones, copper, manganese, micronutrients, nitrogen, calcium

\begin{abstract}
Mouse-ear (ME) is a severe growth disorder affecting pecan [Carya illinoinensis (Wangenh.) K. Koch] trees from southeastern U.S. Gulf Coast Coastal Plain orchards. Slight to moderate ME was substantially corrected by foliar sprays of either $\mathrm{Cu}$ or $\mathrm{GA}_{3}$ shortly after budbreak, but sprays were ineffective for severely mouse-eared trees. Applications of $\mathrm{Cu}, \mathrm{S}$, and $\mathrm{P}$ to the soil surface of moderately affected trees corrected deficiencies after three years. Incorporation of $\mathrm{Cu}$ or $\mathrm{P}$ in backfill soils of newly planted trees prevented $\mathrm{ME}$, whereas incorporation of $\mathrm{Zn}$ or $\mathrm{Ca}$ induced $\mathrm{ME}$ and $\mathrm{Mn}$ was benign. The severe form of ME, commonly exhibited by young trees, appears to be linked to a physiological deficiency of $\mathrm{Cu}$ and/or $\mathrm{Ni}$ at the time of budbreak. It likely occurs as a replant problem in second-generation orchards due to accumulation of soil $\mathrm{Zn}$ from decades of foliar $\mathrm{Zn}$ applications to correct $\mathrm{Zn}$ deficiency.
\end{abstract}

An increase in the incidence and severity of "mouse-ear" (ME), an abnormality of growth and development of pecan [Carya illinoinensis (Wangenh.) K. Koch] trees, has increased its economic significance to pecan farmers of the southeastern United States (Wood et al., 2003). The anomaly was once suspected of being caused by a virus, but was later attributed to a $\mathrm{Cu}$ deficiency, although foliar and soil application of $\mathrm{Cu}$ generally failed to correct symptoms (Gammon and Sharpe, 1956). It was later attributed to an Mn deficiency after leaves dipped in an $\mathrm{MnSO}_{4}$ solution, or $\mathrm{Mn}$ applied to the soil around trees, sometimes appeared to diminish symptoms in subsequent years (Gammon and Sharpe, 1956). Conversely, other researchers reported ME in foliage and trees possessing plentiful Mn (Gallaher and Jones, 1976; Grauke et al., 1983; Worley, 1979). Gallaher and Jones (1976) reported that affected leaflets had more $\mathrm{Ca}, \mathrm{Mn}, \mathrm{Fe}, \mathrm{Cu}, \mathrm{Zn}$, and Mo but less Mg than normal foliage. They concluded that the problem was not due to a deficiency of these nutrients. Worley (1979) studied ME on several different cultivars at different locations and concluded that there were elemental differences between ME and normal foliage, but no clear pattern or relationship could be established.

ME-like symptoms also appear in potted pecan seedlings, suggesting a severe nutrient imbalance involving excessive $\mathrm{N}, \mathrm{S}, \mathrm{Mn}, \mathrm{Ca}$, and lower Fe (Grauke et al., 1983). While no single element has been confirmed as the causal agent in potted trees, the disorder appears to be associated with more than one causal factor. One factor is excessive $\mathrm{N}$ fertilization in an acidic soil media (Grauke et al., 1983). Another

Received for publication 27 Aug. 2002. Accepted for publication 13 Mar. 2003.

${ }^{1}$ To whom reprint requests should be sent. E-mail address: bwwood@saa.ars.usda.gov factor is excessive $\mathrm{Ca}$, in that $\mathrm{ME}$ symptoms increased linearly with the amount of dolomitic lime in the potting mix (Keever et al., 1991). It is uncertain that ME symptoms expressed on trees in the field is the same disorder, or has the same causal factor(s), as the form of ME exhibited by potted seedlings (Grauke et al., 1983).

Wood et al. (2003) described several morphological and physiological symptoms of ME that provided circumstantial evidence that the cause of the disorder was associated with that of a micronutrient deficiency at the time of budbreak. Additionally, circumstantial and anecdotal evidence indicated that $\mathrm{Cu}$ was likely the primary factor, with physiologically active levels potentially subject to modification by other nutrient elements and also by roots damaged by nematode feeding. There are several $\mathrm{Cu}$-based metalloenzymes that are critical to early physiological processes associated with breaking buds and the early stages of shoot and leaf development (Walker and Webb, 1981). The present study tests the hypothesis that the severe form of ME found in pecan orchards is linked to a physiological deficiency of $\mathrm{Cu}$.

\section{Materials and Methods}

Foliar sprays to correct moderate mouseear. An earlier claim, that foliar sprays of $\mathrm{Mn}$ or $\mathrm{Cu}$ corrects $\mathrm{ME}$, was tested. The possibility of correction by other nutritional factors was also tested. Test trees reflected a range in ME severity. Severity classes were: $1=$ no ME; $2=$ trace $(<1 \%$ of foliage being distorted); $3=$ slight ( $1 \%$ to $10 \%$ of foliage being distorted); $4=$ moderate ( $11 \%$ to $50 \%$ being distorted); $5=$ heavy ( $51 \%$ to $99 \%$ being distorted), $6=$ very heavy ( $100 \%$ leaf distortion but no rosetting), and $7=$ severe (i.e., rosetting).

The first study was on 'Wichita' trees $(\approx 12 \mathrm{~m}$ tall) exhibiting a relatively uniform distribution of moderate ME (Class = 4) in the previous growing season. Terminal shoots exhibiting ME symptoms at budbreak were selected for treatment with a single foliar spray of one of several treatments. Treatments consisted of: unsprayed check, $\mathrm{Cu}\left(\mathrm{CuSO}_{4}\right.$ with sulfonate chelating agent at $9.5 \mathrm{~g} \cdot \mathrm{L}^{-1}$; Metagro Liquid Mn, Traylor Chemical Co., Orlando, Fla.), $\mathrm{Zn}\left(\mathrm{ZnSO}_{4}\right.$ at $\left.4.8 \mathrm{~g} \cdot \mathrm{L}^{-1}\right), \mathrm{Mn}$ $\left(\mathrm{MnSO}_{4}\right.$ with sulfonate chelating agent at $9.5 \mathrm{~g} \cdot \mathrm{L}^{-1}$; Metagro Liquid Mn, Traylor Chemical Co.), Fe-chelate (Fe at $1.2 \mathrm{~g} \cdot \mathrm{L}^{-1}$; Novartis Crop Protection, Greensboro, N.C.), B (Solubor at $1.2 \mathrm{~g} \cdot \mathrm{L}^{-1}$; U.S. Borax, Valencia, Calif.), Mo (at $0.13 \mathrm{~g} \cdot \mathrm{L}^{-1}$ ), and gibberellic acid [ProGibb at $5 \mathrm{~mL} \cdot \mathrm{L}^{-1}$ (Abbott Laboratories, North Chicago)]. All treatments contained a nonionic surfactant at $0.1 \% \mathrm{v} / \mathrm{v}$.

Treatments were a single spray applied with a hand sprayer when expanding buds were generally in the "parachute" stage of budbreak (when the expanding shoot was $\approx 3$ $\mathrm{cm}$ elongated and the compound leaves were displayed in a pattern that resembled an open parachute). These eight treatments were randomized within eight branches of eight trees to yield eight single-tree blocks. The experimental design was a randomized complete block (RCB). Developing shoots were positioned to prevent cross contamination among treatments. Shoots were evaluated, after $45 \mathrm{~d}$, for leaf area, severity of ME [based on percentage of affected leaflets per shoot (the percentage of leaflets per shoot that exhibited symptoms, regardless of severity)], and severity class (as described above). The aforementioned study was repeated on 'Desirable' trees exhibiting "severe" ME symptoms and rated for ME severity after $45 \mathrm{~d}$.

Influence of topical soil amendments to existing mouse-eared trees. An orchard of 'Desirable' trees was visually classified as to severity of ME. The efficacy of supplemental nutrient elements applied via broadcasting to the soil under the canopy of affected trees was assessed. The experimental design was a RCB with 10 blocks based on ME severity classes of 3 to 5 (as described above). Nine nutrient element treatments were: 1) untreated control; 2) $\mathrm{S}$ (as flowable sulfur dust at $27.4 \mathrm{~kg} /$ tree); 3) $\mathrm{Ca}$ (hydrated lime at $45.4 \mathrm{~kg} /$ tree); 4) $\mathrm{P}$ (triple superphosphate at $22.7 \mathrm{~kg} /$ tree); 5) $\mathrm{Zn}$ $\left(\mathrm{ZnSO}_{4}\right.$ at $4.5 \mathrm{~kg} /$ tree $\left.) ; 6\right) \mathrm{Mo}\left(\mathrm{Na}_{2} \mathrm{MoO}_{4} \cdot 2 \mathrm{H}_{2} \mathrm{O}\right.$ at $20 \mathrm{~kg} /$ tree $) ; 7) \mathrm{Cu}$ (Cu chelate at $0.5 \mathrm{~kg} /$ tree); 8) $\mathrm{Fe}$ (Fe chelate at $0.5 \mathrm{~kg} /$ tree); and 9) $\mathrm{Mn}$ $\left(\mathrm{MnSO}_{4}\right.$ at $4.5 \mathrm{~kg} /$ tree). Experimental units were single trees ( $\mathrm{n}=90$ trees). Soil amendments were applied in Mar. 1999, and visually rated annually for severity of ME. Data were analyzed by analysis of variance (ANOVA) (SAS Institute, 1990; Stokes et al., 1995).

Influence of soil amendments at time of orchard establishment on the occurrence of mouse-ear. 'Sumner' trees were planted in 1999 as 3-year-old transplants on seedling 'Elliott' rootstocks. Trees were drip irrigated. At the time of tree planting, the $45 \times 91-\mathrm{cm}$ augured planting hole was uniformly backfilled with a mixture of the augured soil plus a specific nutrient element supplement. Nutrient element supplements were either $\mathrm{P}$ (as superphosphate), 
$\mathrm{Ca}$ (hydrated lime), $\mathrm{Mn}\left(\mathrm{MnSO}_{4}\right), \mathrm{Cu}\left(\mathrm{CuSO}_{4}\right)$, or $\mathrm{Zn}\left(\mathrm{ZnSO}_{4}\right)$ at a rate of $0 \mathrm{X}, 1 \mathrm{X}, 2 \mathrm{X}, 4 \mathrm{X}$, or 8X. The amounts applied per hole was: $\mathrm{X}=0.45$ $\mathrm{kg}$ of $\mathrm{P}, 0.45 \mathrm{~kg}$ of Ca, $0.23 \mathrm{~kg}$ of Mn, $0.06 \mathrm{~kg}$ of $\mathrm{Cu}$, and $0.11 \mathrm{~kg}$ of $\mathrm{Zn}$. The experimental design was five nutrient supplenents at five levels structured as a RCB block with eight blocks. Trees were evaluated for ME each year after treatment. Data analysis was by SAS ANOVA and regression analysis (Stokes et al., 1995). Foliage was sampled in early May 2002 when ME began to appear. Soil samples (to $50 \mathrm{~cm}$ depth) were taken from within the backfill zone of the planting hole. Both foliar and soil samples were dried, ground, and nutrient analysis conducted at the Univ. of Georgia's Plant and Soil Analysis Laboratory.

\section{Results and Discussion}

Foliar sprays to correct moderate mouseear. Foliar sprays with micronutrients or ProGibb a few days after outer bud scale split, about the time of the "parachute stage" of leaf expansion (when the compound leaves were unfolded enough to produce a parachute-like shape to the expanding shoot - being $\approx 2$ to 3 $\mathrm{cm}$ in overall length), influenced the severity of ME (Fig. 1). Control shoots exhibited rather severe ME symptoms, whereas those treated with either $\mathrm{Mn}, \mathrm{GA}$, or $\mathrm{Cu}$ exhibited low severity (Fig. 1A). Mn- and GA-treated shoots displayed the least degree of ME (slight to moderate rounding of leaflet tips). ME symptoms were also reduced with $\mathrm{Cu}$, but not nearly as much as by either Mn or GA. Although not evident by the resolution of the rating scale used in this study, shoots treated with Fe displayed an enhanced severity of ME (smaller leaflets and more pronounced cupping of leaflet margins). When rated for percentage of leaflets per shoot exhibiting MErelated growth distortions, it was again evident that $\mathrm{Mn}, \mathrm{GA}$, and $\mathrm{Cu}$, partially corrected ME symptoms of foliage (Fig. 1B). Shoots treated with Mn or GA exhibited $\approx 15 \%$ of the foliage with ME, whereas the control exhibited $98 \%$ and $\mathrm{Cu}$ exhibited $61 \%$. It is especially notable that none of the foliar spray treatments influenced ME of severely affected trees (data therefore not presented).

These results support the occasional partial mitigation of "slight to moderate" $\mathrm{ME}$ symptoms when trees sprayed with either $\mathrm{Cu}$ (by certain farmers) or Mn (by Gammon and Sharpe, 1956). It is, however, noteworthy that success for correcting ME via foliar sprays of $\mathrm{Cu}$ or $\mathrm{Mn}$ has been highly variable and had no beneficial effect on correcting severe ME. A similar lack of success in the correction of $\mathrm{Cu}$ deficiency in peach leaves was reported by Powell et al. (1995). These observations appear to be consistent with the hypothesis that $\mathrm{ME}$ is due to a localized physiological deficiency of one or more micronutrients at the time of budbreak and suggests that the interaction of physiologically available $\mathrm{Cu}$ and $\mathrm{Mn}$ play a role in the manifestation of ME via an influence on gibberellin-related physiological processes during the early stage of shoot and leaf growth. Both $\mathrm{Cu}$ and $\mathrm{Mn}$ are key co-factors of enzymes regulating the synthesis of

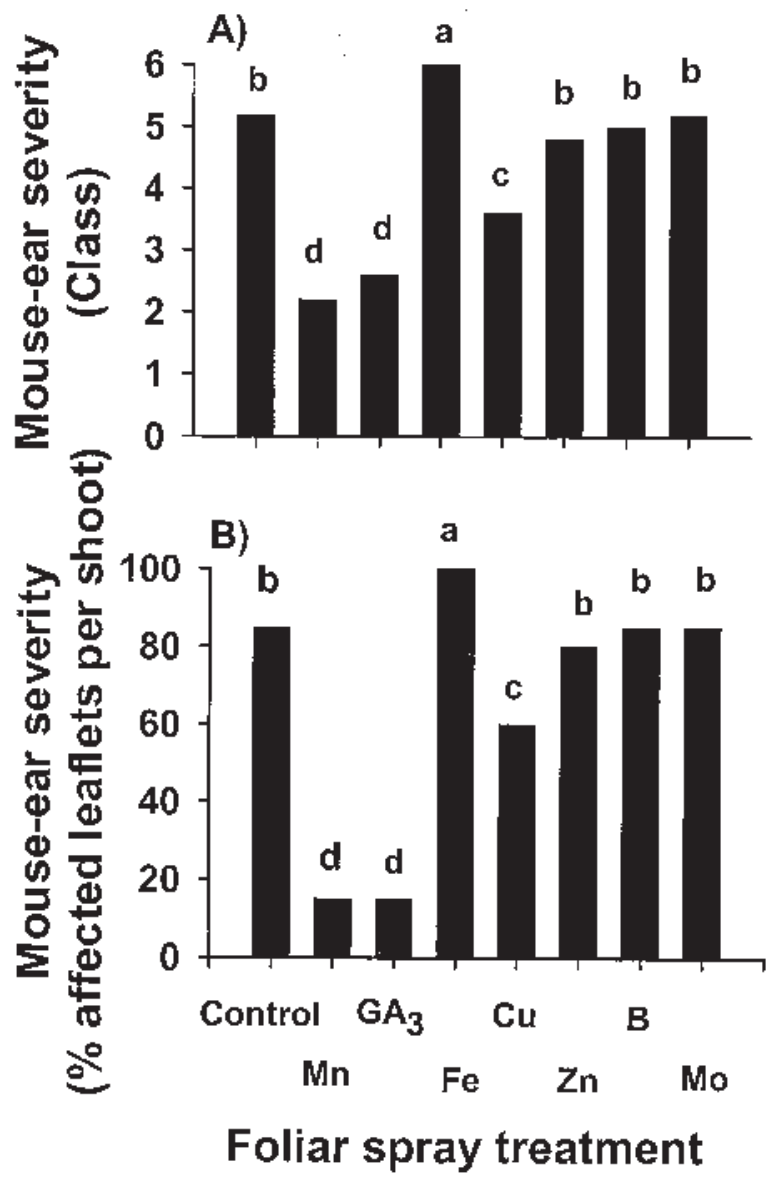

Fig. 1. The influence of foliar sprays of $\mathrm{Mn}, \mathrm{Cu}, \mathrm{Fe}, \mathrm{Zn}, \mathrm{B}, \mathrm{Mo}$, and gibberellic acid (GA as ProGibb) to the foliage ("late parachute stage") of "Wichita' pecan trees in regard to subsequent severity of mouseear on mature foliage (A) and percentage of leaflets per shoot exhibiting cupping (i.e., associated with extreme growth distortions) (B) is illustrated. Mean separation is by $t$ test with treatment means of different letters being different at $P \leq 0.05$.

gibberellins (Hedden et al., 1978; Rappaport and Adams, 1978).

Influence of topical soil amendments to existing mouse-eared trees. Visible ME symptoms of trees with moderate to severe ME were not influenced by topical nutrient elements to soil until the third growing season after treatment (Fig. 2). The topical soil applications of $\mathrm{Cu}, \mathrm{S}$, and $\mathrm{P}$ reduced the percentage of the canopy with ME, whereas $\mathrm{Zn}, \mathrm{Mn}, \mathrm{Fe}$, and Mo had no curative effect. In our study, the foliar Mn concentration of Mn-treated trees was substantially increased by soil applied $\mathrm{Mn}$, but ME symptoms were not influenced. Claims by Gammon and Sharpe (1956) that ME topical soil Mn corrects ME could not be confirmed by the present study. Although, Mn partially corrected symptoms when applied as a foliar spray to moderately (but not severely) affected trees. ME affected foliage had low concentrations of Mn (Wood et al., 2003). The above results indicates that low foliar Mn is not likely the primary cause of the severe form of ME, but is likely somehow involved especially in the slight to moderate forms of ME as noted by Gammon and Sharpe (1956).

These results indicate that $\mathrm{Cu}, \mathrm{S}$, and $\mathrm{P}$ applied to certain soil situations can potentially reduce the severity of ME, given enough time. It is evident that the severity of ME in all treatments, including the control, diminished over the 3-year period. Thus, indicating that, given time, many trees will gradually cease exhibiting visible symptoms; although, they may yet express physiological symptoms associated with a hidden hunger for one or more limiting micronutrients. These results are consistent with the hypothesis that low $\mathrm{Cu}$ is a key factor causing the severe form of ME. This is further supported by the likelihood that the lowered soil $\mathrm{pH}$ by the $\mathrm{S}$ treatment (from 7.0 to $5.5 \mathrm{pH}$ ) increased the soil availability of $\mathrm{Cu}$ by $\approx 100$-fold per unit drop in soil $\mathrm{pH}$ (Tisdale et al., 1993). The P treatment could have possibly increased Cu uptake via its effect on reducing Zn availability in soils (by precipitation; Tisdale et al., 1993) and a subsequent likely reduction in the ability of $\mathrm{Zn}$ to limit $\mathrm{Cu}$ uptake via a shared transport site into the root vascular system (Kochian, 1991).

Influence of soil amendments at time of orchard establishment on the occurrence of mouse-ear. Transplanted trees did not exhibit ME the first two growing seasons after planting. In the third year, there was slight ME in several treatments and also in control trees. There was substantial ME in the fourth growing season. This progression of symptoms in young trees is typical of the occurrence of ME in commercial orchards. Fourth year ratings 
indicated that ME symptoms were strongly influenced by certain soil amendments at the time of planting (Fig. 3).

The inclusion of $\mathrm{Ca}$ in the backfilled soil tended to increase the severity of $\mathrm{ME}$ as the amount of soil $\mathrm{Ca}$ increased, but the relationship was only significant at the $P=0.17$ level (Fig. 3). This trend is in agreement with $\mathrm{Ca}$ induced $\mathrm{ME}$ in potted trees, as was reported by Gofff and Keever (1991) and Keever et al. (1991). Calcium fertilizers reduce $\mathrm{Cu}$ uptake in a variety of agronomic crops (Tisdale et al., 1993). Because high levels of $\mathrm{Ca}$ not only suppresses $\mathrm{Cu}$ uptake, but also reduce its physiological availability via binding by Ca induced phytochelatins (Grill et al., 1985; Grill 1988), it is likely that excessive Ca fertilization induces $\mathrm{ME}$ via phytochelatin binding of heavy metal trace elements necessary for normal growth processes - perhaps involving $\mathrm{Cu}, \mathrm{Ni}, \mathrm{Co}$, or $\mathrm{Cd}$.

Increasing soil Mn had little or no influence on the severity of ME (Fig. 3) where foliar concentrations increased from $\approx 120$ to 700 $\mu \mathrm{g} \cdot \mathrm{g}^{-1}$ (data not shown). This is in contrast to the ability of foliar applied $\mathrm{Mn}$, as described above, to correct ME in cases of slight to moderate severity, but being ineffective in cases of severe ME. These responses are evidence that Mn does not likely play a dominate role in the induction of ME, but may be indirectly involved via interactions with other micronutrients or associated physiological processes.

The severity of ME greatly increased as the amount of $\mathrm{Zn}$ incorporated into the backfill soil increased (Fig. 3). ME severity was extreme (rosetting) when either 0.44 or $0.88 \mathrm{~kg}$ of $\mathrm{Zn}$ were blended with the backfill soil at time of planting. The relationship between ME severity class and foliar $\mathrm{Zn}$ concentration was curvilinear over a concentration range of 25 to $274 \mu \mathrm{g} \cdot \mathrm{g}^{-1}$. Severely mouse-eared trees had 65 to $374 \mu \mathrm{g} \cdot \mathrm{g}^{-1} \mathrm{Zn}$ (Fig. 4A). These data indicate that either relatively high leafZn concentrations or soil $\mathrm{Zn}$ availability can play a key role in the induction of ME. However, there is more involved than simply high foliar Zn concentration, as foliar $\mathrm{Zn}$ concentrations in the 50 to $150 \mu \mathrm{g} \cdot \mathrm{g}^{-1}$ range are common in commercial orchards. Thus, under certain conditions high foliar or soil Zn may possibly lead to a disruption of the physiological action or availability of one or more other elements. Additionally, increasing soil $\mathrm{Zn}$ reduces root absorption of $\mathrm{Cu}, \mathrm{Ni}, \mathrm{Co}$, and $\mathrm{Cd}$ via competitive uptake by a common transport site, but not for $\mathrm{Mn}$ or $\mathrm{Fe}$ - as they appear to use a different transport site (Kochian, 1991). This raises the possibility that $\mathrm{Cu}, \mathrm{Ni}, \mathrm{Co}$, or $\mathrm{Cd}$, or some combination thereof, is the key factor(s) involved in ME.

The induction of severe ME by heavy $\mathrm{Zn}$ fertilization could involve chelation of $\mathrm{Cu}$ (and likely $\mathrm{Ni}$ and other divalent cations) by $\mathrm{Zn}$ induced formation of phytochelatins in tree organs. Phytochelatins are induced by high levels of heavy metals, such as Zn, (Grill et al., 1985) in which a class of heavy metal-binding peptides are produced to bind the excess metal. However, these phytochelatins, once induced, also appear to potentially bind a variety of heavy metals $(\mathrm{Cu}, \mathrm{Ni}, \mathrm{Co}, \mathrm{Cd}, \mathrm{An}$, and $\mathrm{Ca}$ ) other than that of the inducing metal (Zn) (Grill, 1988). Thus, high soil Zn and consequent high plant $\mathrm{Zn}$ in pecan orchards and transplanted trees may induce phytochelatin binding of not only $\mathrm{Zn}$, but also enough $\mathrm{Cu}$ (and possibly $\mathrm{Ni}$ and other heavy metals) to induce a physiological deficiency. A key role for $\mathrm{Cu}$ is indicated by its ability to prevent ME (Fig. 3).

The severity of ME declined as the amount of $\mathrm{Cu}$ incorporated into the backfill soil increased (Fig. 3). While $\mathrm{Cu}$ amounts $>0.06 \mathrm{~kg}$ per hole essentially prevented the expression of ME, they also reduced tree growth, thus, indicating excessive amounts. ME diminished curvilinearly as leaf $\mathrm{Cu}$ concentration increased from 4 to $11 \mu \mathrm{g} \cdot \mathrm{g}^{-1}$ (Fig. 4B). These data indicate that elevating leaf $\mathrm{Cu}$ can prevent $\mathrm{ME}$ and is evidence that ME involves a physiological deficiency of $\mathrm{Cu}$. This is supported by the above-mentioned study in which timely foliar sprays of $\mathrm{Cu}$ or topical application of Cu to soils reduced the severity of ME. Foliar leaf $\mathrm{Cu}$ is typically regarded as being sufficient if above $6 \mu \mathrm{g} \cdot \mathrm{g}^{-1}$ ( $\approx 6$ to $30 \mu \mathrm{g} \cdot \mathrm{g}^{-1}$ ) (Smith, 1991). The validity of this sufficiency range depends upon the concentration of physiologically available $\mathrm{Cu}$. It is noteworthy that the leaf tissues of severely mouse-eared trees usually possess $\mathrm{Cu}$ concentrations within the sufficiency range for pecan. The above-described correction of $\mathrm{ME}$ by $\mathrm{Cu}$ indicates that most of this $\mathrm{Cu}$ is physiologically unavailable at the time of budbreak. High leaf $\mathrm{Cu}$ concentrations are often typical of $\mathrm{Cu}$ deficient plants (Walker and Webb, 1981).

The application of $\mathrm{P}$ to soil backfill at time of planting also reduced ME (Fig. 3). Addition of P to soils increased leaf $\mathrm{P}$ from $1.4 \mathrm{mg} \cdot \mathrm{kg}^{-1}$ in the control treatment to $2.2 \mathrm{mg} \cdot \mathrm{kg}^{-1}$ when

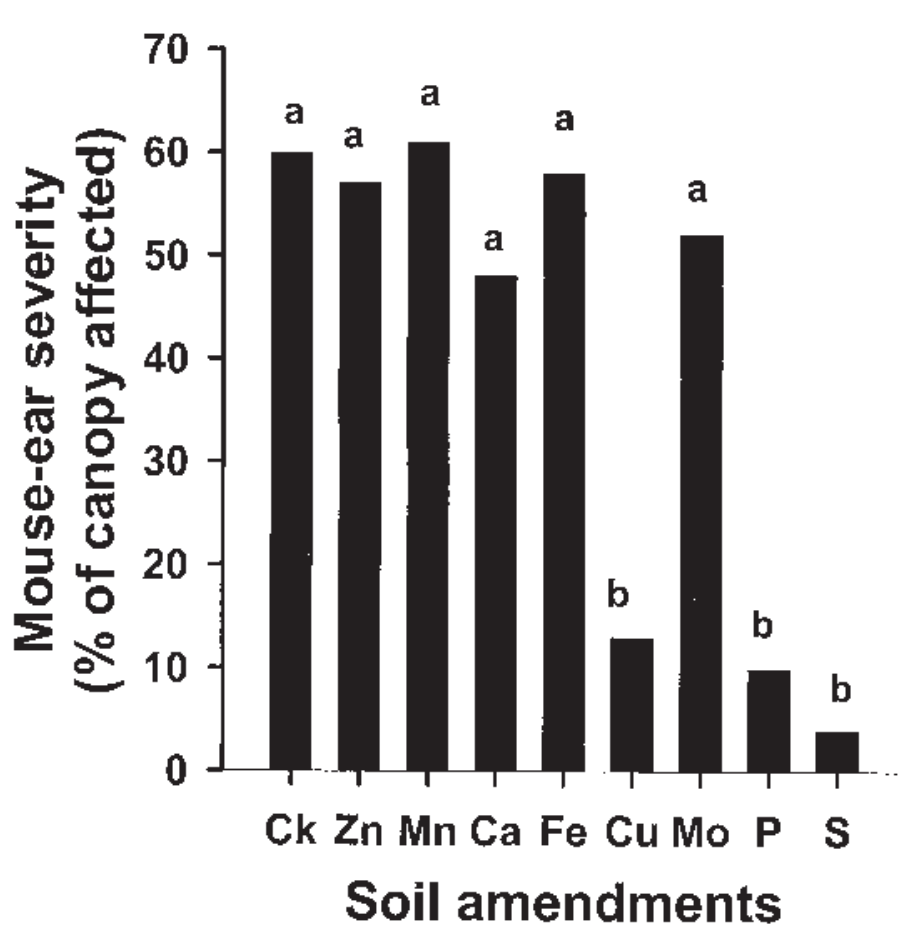

Fig. 2. The influence of applications of several different nutrient elements to the soil surface beneath mouse-ear affected trees is illustrated. Values reflect the percentage of canopy showing mouse-ear in May of the third growing season post-treatment. Mean separation is by $t$ test with treatment means of different letters being different at $P \leq 0.05$.

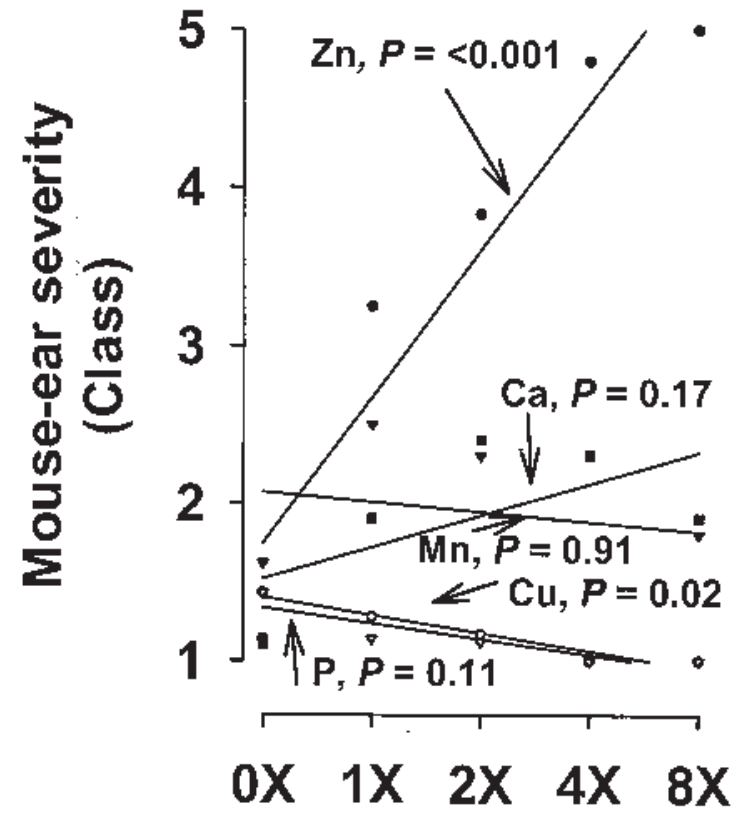

Nutrient element level

Fig. 3. The influence of various nutrient elements on severity of mouse-ear in fourth leaf 'Sumner' trees is illustrated. Nutrient element supplements added with backfill soil at time of planting were either $\mathrm{P}$ (as superphosphate), Ca (hydrated lime), $\mathrm{Mn}\left(\mathrm{MnSO}_{4}\right), \mathrm{Cu}\left(\mathrm{CuSO}_{4}\right)$, or $\mathrm{Zn}\left(\mathrm{ZnSO}_{4}\right)$ at a rate of $0 \mathrm{X}$, $1 \mathrm{X}, 2 \mathrm{X}, 4 \mathrm{X}$ or $8 \mathrm{X}$. The rates were: $\mathrm{X}=0.45 \mathrm{~kg}$ of $\mathrm{P}, 0.45 \mathrm{~kg}$ of $\mathrm{Ca}, 0.23 \mathrm{~kg}$ of $\mathrm{Mn}, 0.06 \mathrm{~kg}$ of $\mathrm{Cu}$, and $0.11 \mathrm{~kg}$ of $\mathrm{Zn}$. 
$3.6 \mathrm{~kg} \mathrm{P}$ was applied (Fig. 5). Foliar $\mathrm{Zn}, \mathrm{Cu}$, and $\mathrm{Ni}$ concentrations declined in a curvilinear manner as foliar $\mathrm{P}$ concentration increased $(\mathrm{K}$, $\mathrm{Ca}, \mathrm{Mg}, \mathrm{Fe}, \mathrm{Mn}, \mathrm{B}, \mathrm{Co}$, and Mo were not influenced) (Fig. 5). Thus, P reduced the uptake of $\mathrm{Zn}, \mathrm{Cu}$, and $\mathrm{Ni}$ from the soil. Phosphorus is reported to react with soil $\mathrm{Zn}$ (and to a lesser degree, $\mathrm{Cu}$ and $\mathrm{Ni}$ ) to produce metallo-phosphates, that are substantially less soluble in the soil solution than are oxides, sulfates, hydroxides, or carbonates (Tisdale et al., 1993). Thus, reducing the amount of $\mathrm{Zn}$ in the soil solution, and, therefore, root uptake of $\mathrm{Zn}$. This appears to be reflected in the lower foliar concentration of $\mathrm{Zn}, \mathrm{Cu}$, and $\mathrm{Ni}$ as Prates increased. Because $P$ reduced uptake of $\mathrm{Zn}$, it potentially alters any effect of high tissue $\mathrm{Zn}$ on physiological processes, especially since high tissue $\mathrm{P}$ appears to interfere with the metabolic function of Zn (Jones, 1998; Olsen, 1972), thus possibly serving to protect $\mathrm{Cu}$ dependent processes from disruption by $\mathrm{Zn}$. Thus, for this specific soil environment, ME was clearly induced by high $\mathrm{Zn}$ and prevented by high $\mathrm{Cu}$ or $\mathrm{P}$.

Because of the inverse effects of increasing foliar $\mathrm{Zn}$ and $\mathrm{Cu}$ concentrations on severity of $\mathrm{ME}$, severity ratings of all treatments were compared to the ratio of foliar $\mathrm{Zn}$ and $\mathrm{Cu}(\mathrm{Zn}$ : $\mathrm{Cu}$ ) (Fig. 6). Under the conditions of this study, severity of ME increased in a curvilinear manner with increasing $\mathrm{Zn}$ : $\mathrm{Cu}$ ratio. Especially severe ME was apparent when this ratio was $\geq 0.30$. According to Fig. 6, a $\mathrm{Zn}: \mathrm{Cu}$ ratio $\geq 0.10$ to 20 is associated with rather severe ME symptoms in 'Sumner' pecan. This result is consistent with a previous study by Worley (1979) in which the mean $\mathrm{Zn}$ : Cu ratio between normal and slight to moderately mouse-eared trees was 15 and 27 , respectively.

These data provide strong evidence that $\mathrm{ME}$ is induced by a physiological deficiency of $\mathrm{Cu}$, as influenced by the $\mathrm{Zn}, \mathrm{Ca}$, and $\mathrm{P}$ (as described below). There appears to be more involved in $\mathrm{ME}$ than the $\mathrm{Zn}$ : Cu ratio because ratios in the 10 to 15 range are fairly common in leaf analysis reports from commercial orchards. This raises the possibility that: 1) it is the ratio of $\mathrm{Zn}$ to physiologically available $\mathrm{Cu}$ (not the absolute amount of $\mathrm{Cu}$ ) that should be measured; and 2) one or more other factors are also influencing the physiological impact of the $\mathrm{Zn}$ : $\mathrm{Cu}$ ratio (perhaps $\mathrm{P}, \mathrm{Mn}$, and $\mathrm{Fe}$ ). It is also possible that other divalent metallic cations (Ni, Co, Ti, or V) (Aller et al., 1990), having an influence on growth processes, may also be involved .

Wood et al. (2003) reported that in many cases ME occurs as a replant problem. This is especially noticeable when trees are planted as a second generation orchard or as a replacement for a large tree that has died. Soil characteristics were compared for locations within the same orchard that supported ME trees (those where 80-year-old 'Success' trees previously grew) and those not exhibiting ME (those planted midway between where 80 -year-old 'Success' trees previously grew). The most notable soil difference between the two sites was about a 2-fold greater amount of $\mathrm{Zn}$ where there was ME. Soil Cu was low at both orchard locations. This is consistent with the above-described studies where $\mathrm{Zn}$ soil amendments increased the severity of ME.

This study demonstrates that, at least in certain cases, ME can be largely corrected by: 1) topical application of $\mathrm{Cu}, \mathrm{S}$, or $\mathrm{P}$ to the soil surface beneath affected trees; 2) application of agricultural grade (which is contaminated with $\mathrm{Ni}$ ) $\mathrm{Cu}$ or $\mathrm{P}$ in the backfill soil of trees at planting; or 3) timely foliar sprays of either $\mathrm{Cu}$, $\mathrm{Mn}$, or $\mathrm{GA}_{3}$ to moderately, but not severely, affected developing shoots. It was also shown that severe ME can be induced by high levels of $\mathrm{Zn}$ and $\mathrm{Ca}$ (to a lesser degree). It is also evident that ME is a replant problem, having a high probability of occurring in certain orchards where transplants are located where older trees previously stood. Such soils had higher $\mathrm{Zn}$ amounts than adjacent soils where trees did not exhibit ME. The occurrence of ME was shown not to be limited to preexisting pecan sites, but can also occur on sites that have never supported pecan or any other

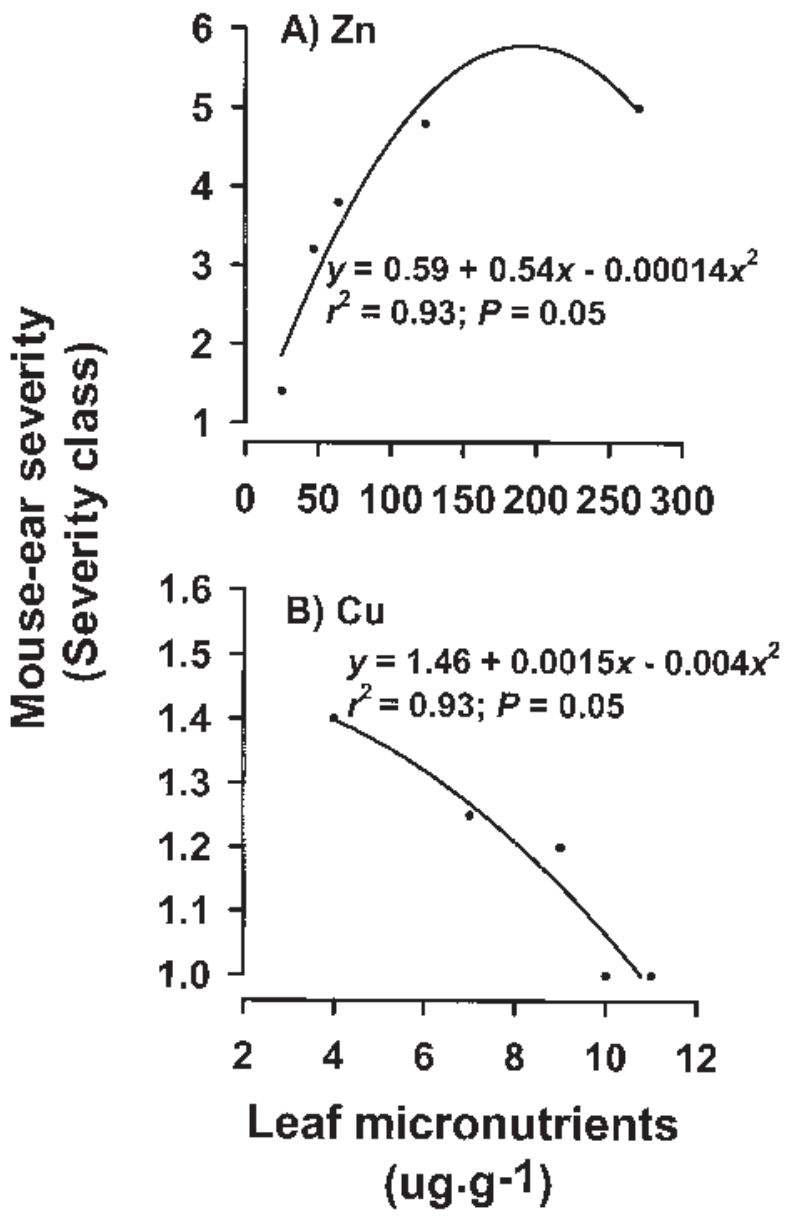

Fig. 4. This illustration describes the relationship between the severity of mouseear and leaf $\mathrm{Zn}$ and $\mathrm{Cu}$ concentrations after application of soil amendments of $\mathrm{Zn}$ and $\mathrm{Cu}$ at time of tree planting.

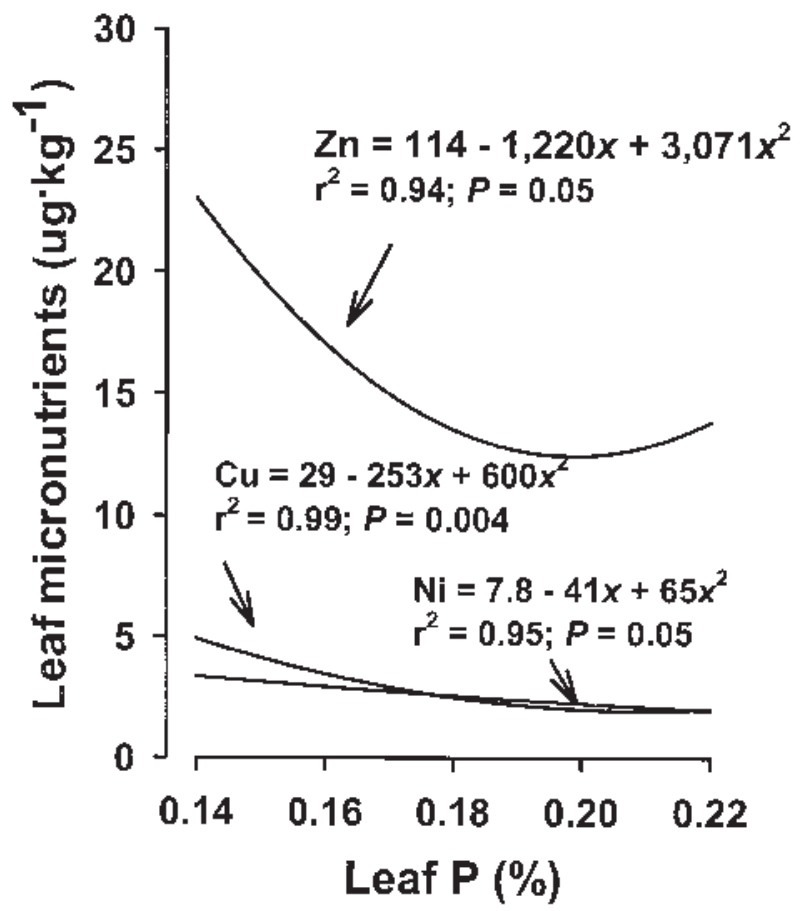

Fig. 5. The relationship between leaf concentrations of $\mathrm{Zn}, \mathrm{Cu}$, and Ni concentrations and that of leaf $\mathrm{P}$ concentration as a result of application of different amount of P to the backfill soil of 'Sumner' trees upon planting. 


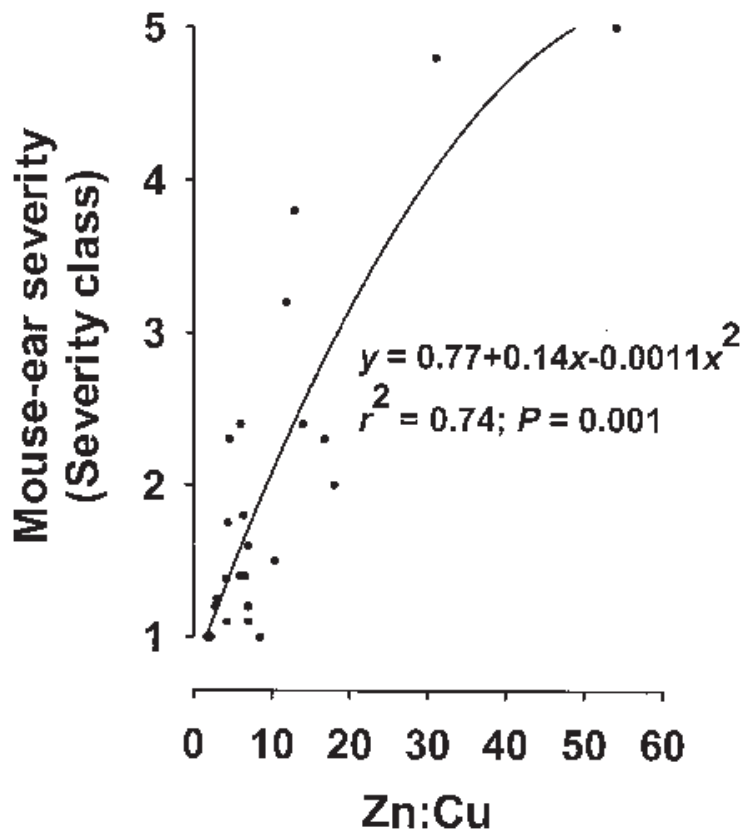

Fig. 6. This illustrates the relationship between mouse-ear severity class and $\mathrm{Zn}$ : Cu ratio for 'Sumner' trees.

horticultural tree crop. Such sites are typically sporadic, possessing low $\mathrm{Cu}$, low $\mathrm{CEC}$, and sandy-textured soils. The replant aspect of ME in second-generation orchards appears to be primarily associated with very high amounts of soil $\mathrm{Zn}$ in low CEC sandy soils that are also low in $\mathrm{Cu}$.

The above-described studies, plus symptomology clues reported earlier (Wood et al., 2003), provide strong evidence that the severe form of ME appearing in regional orchards is primarily due to a deficiency of physiologically available $\mathrm{Cu}$ (Ni and certain other heavy metal micronutrients may also play a role in that $\mathrm{P}$, $\mathrm{Cu}$, and $\mathrm{Mn}$ fertilizers typically contain $\mathrm{Ni}$ as a contaminate) at the time of Spring budbreak This is supported by the fact that of all the essential micronutrients, $\mathrm{Cu}$ is most limited in uptake from the soil solution (Tisdale et al., 1993), is most difficult to translocate within the plant (Kochian, 1991; Welch, 1995), is most difficult to correct by either soil or foliar applications (Kochian, 1991; Robson and Reuter, 1981), and it is especially difficult to assess its status in foliage because of the lack of correlation between total amount in tissues and the amount of physiologically available $\mathrm{Cu}$ (Walker and Webb, 1981). Gammon and Sharpe (1956) reported that ME was due to an $\mathrm{Mn}$ deficiency rather than due to a $\mathrm{Cu}$ deficiency, as had been previously assumed. The present study confirms that Mn likely plays a role at some level, or in certain circumstances, in the expression of ME, but is likely secondary to $\mathrm{Cu}$, as soil amendments of $\mathrm{Cu}$ prevented $\mathrm{ME}$, whereas Mn had no effect on ME. These results also provide limited circumstantial evidence for a possible role for $\mathrm{Ni}$. $\mathrm{Ni}$ is absorbed by the same ion channels in the roots, plays an important role in growth and development of higher plants, and is affected by soil chemistry in a way that is very similar to $\mathrm{Cu}$.

Severely affected ME trees in our studies of $\mathrm{N}$ around budbreak. In the case of agronomic crops, $\mathrm{Cu}$ deficiency is often induced by prolonged or excessive use of $\mathrm{N}$ (Robson and Reuter, 1981). Additionally, excessive usage of $\mathrm{N}$ can delay leaf senescence to the point that $\mathrm{Cu}$ (and likely certain transition metal cations) movement out of older leaves to buds and shoots is greatly reduced (Robson and Reuter, 1981), thus limiting the amount available at the beginning of the next growing season. This indicates that ME-prone sites should not receive excessive or late applications of $\mathrm{N}$, so as to ensure that senescing foliage can translocate $\mathrm{Cu}$ to bud and shoot storage pools prior to defoliation. This effect of $\mathrm{N}$ is consistent with observations reported by Grauke et al. (1983) for potted trees in which ME was linked to excessive $\mathrm{N}$ fertilization.

Copper deficiencies are exacerbated by low soil moisture (Robson and Reuter, 1981). It is noted by the authors that the incidence and severity of ME in pecan is substantially increased in dry Springs. Because $\mathrm{Cu}$ is normally absorbed from the soil solution as $\mathrm{Cu}^{2+}$, and its absorption is among the lowest of any micronutrient (Graham, 1981), it is therefore important that ME preventive management strategies should ensure that soils are moist during the weeks around the time of budbreak.

Zinc management appears to be an especially important component of an effective strategy to prevent ME. Because $\mathrm{Zn}$ is a competitive inhibitor of $\mathrm{Cu}$ (and $\mathrm{Ni}$ ) uptake by roots, soil Zn levels should not be allowed to increase in low CEC soils that are already low in $\mathrm{Cu}$ (or possibly $\mathrm{Ni}$ ). Pecan has a relatively high $\mathrm{Zn}$ requirement and typically receives several foliar $\mathrm{Zn}$ sprays in early Spring to prevent $\mathrm{Zn}$ deficiency. This practice has been orchards since the 1930s. Typical applications of $\approx 4 \mathrm{~kg} \cdot \mathrm{ha}^{-1}$ of $\mathrm{Zn}$ per growing season, over a grew in orchards receiving substantial amounts repeated annually in many mature southeastern period of $\approx 70$ years, have resulted in substantial amounts of $\mathrm{Zn}$ accumulating in the soil of old orchards. This accumulation is naturally concentrated around the base of trees, because of rain water rinsing foliar applied $\mathrm{Zn}$ down scaffold limbs and the trunk. This appears to be a key reason why trees transplanted in existing orchards to replace missing trees often exhibit severe $\mathrm{ME}$ within 2 to 3 years after planting. Thus, as with agronomic crops in areas of $\mathrm{Cu}$ deficiency, the application of $\mathrm{Zn}$ may merit careful control, especially on coarse-textured soils. This is because of its ability to induce $\mathrm{Cu}$ deficiency via competitive inhibition of $\mathrm{Cu}$ uptake by roots (Olsen, 1972). Therefore, $\mathrm{Zn}$ management strategies for pecan might need to be reevaluated regarding the potential for long-term adverse effects when pecan is grown on low $\mathrm{Cu}$ (or low $\mathrm{Ni}$ ) soils [i.e., those mineral soils $<6 \mu \mathrm{g} \cdot \mathrm{L}^{-1} \mathrm{Cu}$ (Lucas and Knezek, 1972)], especially many of those so common in the Gulf Coast Coastal Plain of the southeastern United States, where a large portion of the U.S. pecan belt is located.

The role of $\mathrm{P}$ management in regard to $\mathrm{ME}$ is unclear because, depending on the situation, $\mathrm{P}$ can influence plant $\mathrm{Cu}$ status in opposing ways. For example, increasing soil $\mathrm{P}$ on soils high in $\mathrm{Zn}$ would appear to increase plant $\mathrm{Cu}$ by reducing soluble $\mathrm{Zn}$ in the soil solution, thus reducing the competitive inhibition of $\mathrm{Cu}$ uptake by $\mathrm{Zn}$ in roots. Conversely, increasing $\mathrm{P}$ in soils low in both $\mathrm{Cu}$ and $\mathrm{Zn}$ could potentially reduce $\mathrm{Cu}$ uptake. This is why $\mathrm{Cu}$ toxicity in citrus was historically corrected by application of P(Reuther, 1957). Additionally, high foliar P may possibly have an effect on the physiologically availability of $\mathrm{Cu}$, as it has been shown to have for Fe and Zn (Cakmak and Marschner, 1987; Tisdale et al., 1993). Thus, efforts to manage ME via $\mathrm{P}$ would appear to be complex; however, in cases where ME appears to be substantially induced by high soil $\mathrm{Zn}$, applications of $\mathrm{P}$ might prove beneficial (as was the case in the above-described study with soil amendments at the time of transplanting), but would likely be detrimental if soils are low in both $\mathrm{Zn}$ and $\mathrm{Cu}$ (Cakmak and Marschner, 1987).

Excessive $\mathrm{Ca}$ fertilization (i.e., liming) could also potentially influence ME because of its adverse effect on $\mathrm{Cu}$ uptake by roots. This is consistent with observations by Keever et al. (1991) and Goff and Keever (1991) in that increasing $\mathrm{Ca}$ in potted trees substantially increased the severity of ME. Thus, excessive application of Ca to ME-prone sites may enhance the incidence and severity of ME.

Sulfur management may also be of potential importance for the control of ME. In the above-described studies where $S$ was typically applied to soils, ME was corrected after 3 years. It is likely that this was via the ability of $\mathrm{S}$ to reduce soil $\mathrm{pH}$ and subsequent increase in $\mathrm{Cu}$ uptake. Because the availability of $\mathrm{Cu}$ in the soil solution increased by 100 -fold for each full unit drop in soil pH (Tisdale et al., 1993), acidification of low $\mathrm{Cu}$ soils might be expected to reduce ME. However, this might prove counterproductive in soils with low $\mathrm{Cu}$ and high $\mathrm{Zn}$, because acidification would also increase 
the availability of $\mathrm{Zn}$, which would in turn competitively inhibit $\mathrm{Cu}$ uptake by roots.

As in the above-mentioned study, spring foliar application of $\mathrm{Cu}$ to "severely" affected trees at, and soon after, budbreak did not correct ME, as it did in slight to moderately affected trees. This indicates that foliar applied $\mathrm{Cu}$ is either insufficiently absorbed, is not mobilized, or is not physiologically available at sites of activity, or is not the only limiting micronutrient. The transportation and redistribution of $\mathrm{Cu}$ in plants is in certain ways much more complicated than other nutrient elements (Kochran, 1991). Efforts to correct micronutrient deficiencies via foliar application are more difficult with $\mathrm{Cu}$ than any other essential micronutrient (Kochian, 1991). This is because $\mathrm{Cu}^{2+}$ binds strongly to organic $\mathrm{N}$-ligands, such as proteins (Walker and Webb, 1981). Thus, $\mathrm{Cu}$ entering leaf tissues is quickly bound to proteins and cell walls, and quickly becomes physiologically unavailable until proteins are disassembled during senescence processes and the bound $\mathrm{Cu}$ is exported out of the leaves as complexes with $\mathrm{N}$ containing compounds to storage pools (Walker and Webb, 1981; Welch, 1995). Because the mobility of Cu in the phloem and xylem is largely dependent upon the binding of ions to amino acids, amides, and ureides (Welch, 1995), co-application of foliar Cu with phytometallophores, such as nicotianamine, could potentially increase the physiological availability of Cu (Welch, 1995). These characteristics of $\mathrm{Cu}$ transportation and redistribution indicate that efforts to correct $\mathrm{ME}$ with foliar $\mathrm{Cu}$ might be much more successful if $\mathrm{Cu}$ is coapplied with a phytometallophores, especially when application is during the postripening interval when senescence processes translocate $\mathrm{Cu}$ containing organic $\mathrm{N}$-ligands to dormant season storage pools, which in turn increases the supply of physiologically available $\mathrm{Cu}$ to breaking buds the following Spring.

\section{Conclusions}

The findings of this study are consistent with the hypothesis that the "severe" form of $\mathrm{ME}$ in orchard trees is linked to a physiological deficiency of $\mathrm{Cu}$ in buds at budbreak, but do not exclude the possible involvement of $\mathrm{Ni}$ and similar metals. Evidence suggests that excessive applications of $\mathrm{Zn}, \mathrm{P}, \mathrm{Ca}$, or $\mathrm{N}$ to low $\mathrm{Cu}$ soils can potentially enhance the incidence and severity of ME. This indicates that orchard management to prevent ME might include efforts to ensure that low $\mathrm{Cu}$ soils do not accumulate excessive $\mathrm{Zn}, \mathrm{P}$, and $\mathrm{Ca}$; that soils are moist at time of budbreak; that $\mathrm{N}$ is not applied until after budbreak; and that trees do not receive late-season $\mathrm{N}$ in amounts sufficient to delay senescence and the associated translocation of $\mathrm{Cu}$ into dormant-season storage pools. Additionally, application of S to "low $\mathrm{Cu}$ and low Zn" soils, or the application of $\mathrm{P}$ to "low $\mathrm{Cu}$ high $\mathrm{Zn}$ " soils, may also moderate ME symptoms. The replant associated form of ME appears to be due to a $\mathrm{Zn}$-induced $\mathrm{Cu}$ deficiency associated with an accumulation of $\mathrm{Zn}$ from decades of foliar $\mathrm{Zn}$ application. Additionally, the loss of absorptive surface due to nematode feeding and galling of roots might also potentially contribute to reduced micronutrient uptake.

These findings indicate that research efforts to fully understand the ME problem would benefit from: 1) developing strategies to enhance physiological availability of $\mathrm{Cu}$ at time of budbreak; 2) determining how available $\mathrm{Cu}$ is influenced by endogenous $\mathrm{Zn}, \mathrm{P}$, and Mn; 3) ascertaining the role other micronutrients (i.e., $\mathrm{Ni}$ ) that are absorbed via the same uptake sites in roots; 4) characterizing soil conditions that predispose a site to be prone to ME; 5) refining orchard management strategies to prevent and correct ME; 6) ascertaining the role of root localized biological agents (nematodes and mycorhizae); 7) using enzymatic methods to assess the activities of metalloenzymes at time of budbreak; and 8) having a better understanding of the influence of $\mathrm{Zn}$ (and possibly Ca) induced phytochelatins on physiologically available $\mathrm{Cu}$ and $\mathrm{Ni}$.

\section{Literature Cited}

Aller, A.J., J.L. Bernal, M.J. Nozal, and I. Deban. 1990. Effects of selected trace elements on plant growth. J. Sci. Food and Agr. 51:447-479.

Cakmak, I., and H. Marschner. 1987. Mechanism of phosphorus-induced zinc deficiency in cotton. III. Changes in physiological availability of zinc in plants. Physiol. Plantarum 70:13-20.

Gallaher, R.N. and J.B. Jones, Jr. 1976. Total extractable, and oxalate calcium and other elements in normal and mouse-ear pecan tree tissue. J. Amer. Soc. Hort. Sci. 101:692-696.

Gammon, N. and R.H. Sharpe. 1956. Mouse-ear: A manganese deficiency of pecans. Proc. Amer. Soc. Hort. Sci. 68:195-200.

Goff, W.D. and G.J. Keever. 1991. Omission of lime reduces mouse-ear symptoms in container-grown pecan trees. HortScience 26:383-386.

Graham, R.D. 1981. Absorption of copper by plant roots, p. 141-163. In: J.F.Lonergan.(ed.). Copper in soils and plants. Academic, New York.

Grauke, L.J., H.J. Morris, and J.G. Kowalczuk. 1983. Mouse-ear: A symptom of nutrient imbalance. Proc. Southeastern Pecan Growers Assn. 76: 141-147.

Grill, E. 1988. Phytochelatins in plants, p. 283-300. D.H. Hamer and D.R. Winge (eds.). In: Metal ion homeostasis. UCLASymp. Mol. and Cellular Biol., New Ser., vol. 98. A.R. Liss, New York. Grill, E., E.L. Winnacker, and M.H. Zenk. 1985.
Phytochelatins: The principal heavy metal complexing peptides of higher plants. Science 230:674-676.

Hedden, P.J. MacMillan, and B. Phinney. 1978. The metabolism of gibberellins. Ann. Rev. Plant Physiol. 28:149-192.

Jones, J.B. 1998. Phosphorus toxicity in tomato plants: When and how does it occur? Commun. Soil Sci. Plant Anal. 29:1779-1784.

Lucas, R.E. and B.D. Knezek. 1972. Micronutrient interactions. p. 265-288. In: R.C. Dinauer (ed.). Micronutrients in agriculture. Soil Sci. Soc. Amer., Madison, Wisc.

Keever, G.K., W.D. Goff, and M.S. West. 1991. High dolomitic lime rates induce mouse-ear symptoms in container-grown pecan trees. HortScience 26: 1494-1495.

Kochian, L.V. 1991. Mechanisms of micronutrient uptake and translocation in plants, p. 229-296. In: R.J. Luxmoore (ed.). Micronutrients in agriculture, $2^{\text {nd }}$ ed. Soil Sci. Soc. Amer., Madison, Wisc.

Olsen, S.R. 1972. Micronutrient interactions, p. 243-264. In: R.C. Dinauer (ed.). Micronutrients in agriculture, Soil Sci. Soc. Amer., Madison, Wisc.

Powell, J.C., C.G. Lyons, and V.A. Haby. 1995. Effects of copper, zinc, and sulfur application to peach trees on Coastal Plane soil. Commun. Soil. Sci. Plant Anal. 26:1637-1648.

Rappaport, L. and D. Adams. 1978. Gibberellins: synthesis, compartmentation and physiological process. Physiol. Trans. Royal Soc. London. 284:521-539.

Reuther, W. 1957. Copper and soil fertility, p. 128-135. In: Soil, the yearbook of agriculture. U.S. Gov. Printing Office, Washington, D.C.

Robson, A.D. and D.J. Reuter. 1981. Diagnosis of copper deficiency and toxicity, p. 287-312. In: J.F. Loneragan, A.D. Robson, and R.D. Graham (eds.). Copper in soils and plants. Proc. Golden Jubilee Intl. Symp., Murdoch Univ., Perth, Western Australia. Academic, Perth, Australia.

SAS Institute. 1990. SAS/graph software reference, vers. 6, vol. 2. SAS Inst., Cary, N.C.

Smith, M.W. 1991. Pecan nutrition, p. 152-158. In: B.W. Wood, J.A. Payne (eds.). Pecan husbandry: Challenges and opportunities. U.S. Dept. Agr., ARS-96.

Stokes, M.E., C.S. Davis, and G.G. Koch. 1995. Categorical data analysis using the SAS System. SAS Inst., Cary, N.C.

Tisdale, S.L., W.L. Nelson, J.D. Beaton, and J.L. Havlin. 1993. Micronutrients and other beneficial elements in soils and fertilizer, p. 305-363. In: P.F. Corey (ed.). Soil fertility and fertilizers. Macmillan, New York.

Walker, C.D. and J. Webb. 1981. Copper in plants: Forms and behaviour, p. 189-212. In: J.F. Loneragan, A.D. Robson, and R.D. Graham (eds.). Copper in soils and plants. Proc. Golden Jubilee Intl. Symp., Murdoch Univ., Perth, Western Australia. Academic, Perth, Australia.

Welch, R.M. 1995. Micronutrient nutrition of plants. Critical Rev. in Plant Sci. 14(1):49-82.

Wood, B.W., C.C. Reilly, and A.P. Nyczepir. 2004. Mouse-ear of pecan: I. Symptomatology and occurrence. HortScience 39:1563-1570.

Worley, R.E. 1979. Pecan cultivars differ in leaf 